Brit. J. vener. Dis. (1955), 31, 113.

\title{
PROSTITUTION* +
}

\author{
BY \\ ELEANOR FRENCH
}

British Social Biology Council, London

There are two main approaches to the problem of prostitution : the medical and the social. To the venereologist the chief interest in prostitution must be that it provides the main reservoir of infections and re-infections. But in comparison with the social approach, the medical aspect presents a simple problem.

In 1949 the British Social Biology Council undertook a small survey $\ddagger$ of prostitution in London. The first step, mainly statistical, was undertaken jointly with the London School of Economics and consisted of an examination of the records of Scotland Yard, which was carried out by permission of the Commissioner of Police, Sir Harold Scott. As it was not possible to study all existing records of prostitutes it was decided to take those of one year immediately after the second world war and one year in more normal times. The years 1946 and 1949 were accordingly chosen. We extracted from the records the comparative statistics for soliciting and other relevant offences, the ages of prostitutes involved, the number of their arrests and other charges against them, as well as the numbers of prostitutes convicted in both years, and so on. A detailed analysis of a random selection of 150 case records was then compiled, and from these we have obtained information about the place of birth of the prostitute, her total number of charges for soliciting, changes in districts, and age of first conviction, the number of years between her first and most recent conviction for soliciting, her nationality, her juvenile and adult police record, with the type of offence before and after conviction for soliciting. We also obtained information, where possible, on the education she had received, her home conditions, her previous occupation, her age on coming to

* Received for publication December 30, 1954.

+ Read to the M.S.S.V.D. November 27, 1954.

$\ddagger$ This survey was published by the British Biology Council (1955).
London, her marriage, the number of children, her consorts, her criminal associates, and her personal and social situation on becoming a prostitute.

Talking about prostitution has certain very real handicaps : the first is that there is so little written material on which to draw. Outstanding publications include those of Flexner (1914), Freed (1941), Glover (1945), Hewitt (1951), and Bennett (1954). Surveys have also been undertaken by the League of Nations (1938a, b ; 1943) and the Los Angeles Dept. of Public Health (1945). There is very little else that is new, beyond the startling statement from Russia that prostitution has been abolished there.

A second difficulty is that, while factual knowledge that can be checked is meagre, the veritable jungle of folklore surrounding the subject tends to cloud one's thinking.

It is also a subject which brings the emotions into play, for I need only remind you that prostitution, regarded as the exploitation of women by the male, has been, and to a lesser degree still is, linked with the struggle for female emancipation and equality of the sexes.

Types.-It is impossible and unwise to attempt to describe " a prostitute type". They vary enormously in age, in intelligence, in social class, they may be married or single, they may come from country or town, they may be physically sound or grossly handicapped. But it is significant that the prostitutes who have been studied by research workers have almost inevitably been the failures, those who have been through the courts, or have broken down and needed social and medical treatment. Our knowledge of the successful prostitute, who does not need help and has no police record, is practically nonexistent.

It does appear from the available material, however, that they do come mostly from a poorer economic background. But even this conclusion 
should be treated with caution, for it may also indicate that the early school-leaving age has something to do with it too, not to mention poor housing. In Johannesburg, on the other hand, where conditions are very different, it is clearly shown that poor wages for women workers are the main cause of prostitution.

The suggestion frequently made that prostitutes are mainly of poor intelligence should also be received with caution. We have not the necessary data on the successful prostitute on which to base a judgment.

We need to know much more about the precipitating causes, the family background and so on, before we can even make a guess at why one girl becomes a prostitute and another girl in similar circumstances does not. There is an enormous amount of work still to be done in this field and, until a full-scale research is carried out, any opinions can only be personal ones. It is much to be regretted that grant-giving bodies appear to have placed a taboo on the subject.

But once having crossed the line to prostitution, the girl becomes a member of a minority group, not actively persecuted but definitely ostracized, and she swiftly develops the psychological attitudes of such a group. She is at war with society, and loses what sense of responsibility for her actions she may have had. To the outsider-and this includes the client-she lies only too easily and pleasantly about herself. She has a tremendous loyalty to other prostitutes, though this loyalty may not last very long, for violent quarrels and reconciliations are part of her everyday life. She will rush to help any friend in difficulty and smother her with kindness regardless of the cost. It has been suggested that this extreme generosity is a compensatory mechanism and is really a form of "mothering". For prostitution in itself is a rejection of maternity and the prostitute's guilt feelings, recognized by her or not, as well as the claims and fulfilment of her biological function, find an outlet in this maternal attitude to a sister in trouble, and here probably lies the explanation of the attitude of the better type to her male customer. Often, however, this extreme generosity, though genuine, may be quite superficial. The friend she is helping is perhaps in hospital or prison, yet she will not hesitate to go to her room in her absence and steal her belongings. One reads too reports in the papers of how she will defend her " beat" from intruders, using physical violence on occasion. The prostitute is not as a rule the oversexed girl who enjoys the physical side of her life. Indeed, she takes a pride in the fact that she is frigid with her client. whom she despises quite as much as he despises her. She nearly always has a man friend in the background, however, with whom she finds her satisfaction, and by whom she may even have a child or children. He very often acts as her "ponce" and plays a very important part in her life, giving her some sense of security, and easing her essential loneliness.

I would stress again that most of our knowledge about prostitutes comes from the study of the unsuccessful ones, those who have police records, or those who have fallen on evil days. We know little of the successful ones. There is a certain type, however, whom one cannot ignore : the refined and kindly prostitute who acts as a friend to the lonely man and appears from his accounts to be thoroughly decent. One is told so often about her that she must exist in some numbers, but the only one of this type whose history, as told to the client, I have known to be checked, turned out to be a very different person from the picture given by the client. Instead of being a heartbroken war-widow with a child to educate, with nothing left in life except the desire to help others (the others, of course, being men in search of sexual companionship), she turned out to be single, but living with a criminal, and with a record herself of receiving stolen goods. Perhaps it is cynical, but I should like to suggest the possibility that some of these "good sorts" may be the top-level experts at their job who cash in on the needs of the lonely man whose marriage and sex life are unsatisfactory. For it is the prostitute's job to give the man the satisfaction he asks for and in the way he wants it, and it is the measure of her skill that she appears to do it with such success. And, in parenthesis, I should like to add that if more women understood and studied the art of being wives instead of taking their position for granted, there would be a sharp decline in the number of prostitutes and many more happy and lasting marriages. Yes, some wives could learn a great deal from some prostitutes!

Link between Prostitution and Crime.-The link is a real one, but the prostitute herself is, as a rule, guilty of only minor offences. For a woman prostitution is accepted as the crime par excellence, and one should bear this in mind when studying criminal statistics. But while she herself may not have a bad criminal record, she does associate with criminals. Out of 150 prostitutes in our survey, 64 were known to have associated at some time with men and women (not prostitutes) who were criminals. 72 men who associated with these 64 prostitutes had crime records ranging from larceny (27), housebreaking (sixteen), and assault (ten), to shooting a police constable on duty (one). 
Not only is the link with crime a real one, but there is an even darker side to the picture, for where prostitution exists among the wealthier sections of a community, it is inevitably tied up with vice and perversions, and this must not be forgotten if we are to form a true picture of what prostitution involves. Prostitution is not legally a crime, any more than adultery or fornication, but it acts as a kind of magnet that attracts to itself the worst elements of society, the third party exploiter, and the criminal. For this reason alone we cannot be indifferent to the problems it presents.

The Call-Girl System.-This is a comparatively new development in prostitution, and seems to have superseded the brothel to a large extent, though once again the factual evidence for this is lacking. The system has developed with the introduction of the telephone, and in the U.S.A., where it is the policy to clear prostitution off the streets, is more highly organized than in this country. Here is an example of one way in which the system works : there is a tobacconist in the West End where a man can go and say he wants a woman; he is then shown several albums of photographs from which to choose the girl he fancies ; this done, the tobacconist pushes over a card to the customer and gives him a telephone number to write down. The tobacconist charges a guinea for this service, and the girl charges three guineas for about half an hour, or five guineas if she is taken out to dinner first. The flat where she is visited is usually in a very respectable block.

An interesting point about this system is that here the amateur and professional girls meet, for the goodtime girl, the young and silly girl out for adventure, perhaps even the student trying to get through her course on an inadequate allowance, and the professional prostitute are all found among the call girls. Its disadvantage as against street importuning is the opportunity it gives for exploitation.

Remedies.-In considering possible answers to the problems presented to us by prostitution, one must be realistic. Unless one can offer the prostitute very high wages for irregular hours of intermittent work which is interesting and exciting, involving contact with members of the opposite sex, she is not likely to alter her way of life. Temperamentally, and if she has been at the game for long, she is unfitted for the daily round of routine work. After all, she has become a prostitute because she is a misfit and is maladjusted to society, and she remains one because she has found a circle in which she is accepted and a way of life that offers her the things she wants-easy money, no responsibility, and no necessity for regular hours of work, even though it does involve hardship and even danger. I do not suggest by this that we should not keep the way open for her if she wishes to rehabilitate herself, for we most certainly should, and our survey has shown that she is aware of the possibilities and means of doing so. But I do not think that we are going to make much headway by a direct approach to the well-established prostitute.

Something, however, could and should be done to make the conditions of the trade such that it will not be attractive to the young recruit. It is our duty and responsibility to the younger generation to do so, and by far the greatest responsibility that we have to the prostitute and potential prostitute. Short of penalization, we should take every possible step to achieve it. It is interesting that quite a number of established prostitutes, when asked about their profession, have expressed grave concern for the younger ones under 21 years, and have even urged that they should be taken right away off the streets, by force if necessary, in an attempt to induce them to give up the game before it is too late. The process of "putting back" a young prostitute for a medical examination now used by some magistrates is a step in the right direction, and could, I think, be developed much further. It is, in my opinion, the strongest argument in favour of increasing the fine, that it will deter at least the beginner and the older prostitute, and may be the cause of their quitting the profession. Let us get the idea out of our minds that the prostitute's position today is the same as it was in 1870 , when she was a victim of poverty and preyed upon by society. She is indeed still to be pitied but for different reasons, for now it is she who, driven by no economic compulsion, preys upon the community. Why then should we not make the conditions of her profession as difficult for her as possible?

Having said this, I would make a qualification here about economic necessity. Up to quite recently it has been the policy of voluntary agencies to use every possible persuasion to insist that the unmarried mother should keep her baby, regardless of her circumstances and family background. But at the same time, unbelievably, no record has been kept or follow-up done into the results of this policy. We know that many prostitutes have illegitimate children ( 22 per cent. in the survey). I would suggest that this policy may well have helped to swell their ranks, for it is a very difficult economic problem to provide for two people out of a small pay packet, especially when one of them is a young child. The fate of the prostitute's child as it grows up hardly bears thinking about. 
The indirect approach to the problem is surely the most hopeful. Supply should in every way possible be prevented from creating the demand, even though the economist may shudder at the thought. It has been said that 15 per cent. of men will find a prostitute however difficult it be, another 15 per cent. will not go near one however readily available, and the remaining 70 per cent. will go to one if it is made more or less easy. It is this 70 per cent. that should interest us, and to whom we owe it to keep the streets as clean as we can.

There is another point which cannot be ignored. Have we not also a responsibility to the young man who has left school and is starting out in life? Do we not owe him something too ? Should we not try to give him some protection from the prostitute, who is always ready for him when he is particularly vulnerable after an evening's amusement?

We know that certain social and home conditions are conducive to anti-social behaviour; one can only just touch on them. Freed (1941) indicated that there may be a correlation between prostitution, the marriage rate, and the number of unmarried women in the population. If he is correct, then we should aim at removing all obstacles to early marriage. Bad housing too plays its part and is a contributory factor to prostitution, for overcrowding, with the whole family sleeping together in one room, cannot afford a good start in life, and one cannot blame the girl who will do almost anything to escape from such conditions. As it is, she acquires a precocious knowledge of sex in the worst possible way, which makes it all the easier for her to take to the game.

This brings me to the vexed question of sex education. Much has been done and many hopes have been raised by its widespread adoption. Indeed, prostitutes have often given their ignorance about sex as one of the factors in their taking to the life. This ignorance will be confirmed by anyone who has worked in a fertility clinic, where quite a number of couples who come for advice have never consummated their marriage through sheer lack of knowledge. But one may have a comprehensive knowledge of the anatomy and physiology of sex, and yet that knowledge may be of no help but rather may be a positive hindrance if one's attitude towards sex is wrong. And this leads one to the heart of the problem of prostitution-it is this too generally accepted divorce of sex from its true context expressed in the love of a man and a woman. Love and sex are a unity; when they cease to be so and become a dichotomy, you have their incomplete and immature expression in isolation, on the one hand in prostitution, and on the other in a romantic celluloid love based solely on emotion without knowledge.

\section{REFERENCES}

Bennett, R. (1954). Practitioner, 172, 381

British Social Biology Council (1955). "Women of the Streets : a Sociological Study of the Common Prostitute." Ed. by C. H. Rolph. Secker and Warburg, London.

City and County of San Francisco Department of Public Health (1945). "An Experiment in the Psychiatric Treatment of Promiscuous Girls." (Los Angeles.)

Flexner, A. (1914). " Prostitution in Europe." Century Co., New York.

Freed, L. F. (1941). “The Problem of European Prostitution in Johannesburg."

Glover, E. (1945). “"The Psycho-Pathology of Prostitution.” Institute for the Scientific Treatment of Delinquency, London. Association for Moral and Social Hygiene.

Hewitt, C. R. (1951). “ The Police and the Prostitute."

League of Nations (1938a). "Prostitutes ; Their Early Lives." Geneva.

(1938b). " Enquiry into Measures of Rehabilitation of Prostitutes." Geneva.

- (1943). "Prevention of Prostitution." Geneva. 